\title{
EFFECT OF DEXAMETHASONE IN THE TREATMENT OF THE DISTURBED KIDNEY FUNCTIONS CAUSED BY PARAQUAT ADMINISTRATION OF TO ADULT MALE RATS
}

\author{
RANA A. ASIM, MAN S. KALO* and SOULAF J. KAKEL \\ Department of Physiology, Biochemistry \& Pharmacology \\ College of Veterinary Medicine, University of Mosul \\ *E-mail: maan kallo@yahoo.com
}

\section{ABSTRACT}

Received at: 28/6/2012 function tests in experimental paraquat intoxication in male rats. Three groups of

Paraquat (PQ) is highly toxic herbicide with no specific antidote. this study was conducted to evaluate the therapeutic potency of dexamethasone (Dx) on the kidney rats were subjected to this trial, control, PQ group (50 mg/ kg orally) and PQ with Dx $(50 \mathrm{mg} / \mathrm{kg}$ orally, $4 \mathrm{mg} / \mathrm{kg}$ ip. respectively) throughout 15 days. Results revealed that treatment with PQ caused an elevation in kidney function indices as well as sodium ion and decrease in each of potassium, calcium ions and inorganic phosphate compared to control whereas treatment with Dx decreased $(p \leq 0.05)$ the concentration of both creatinine and inorganic phosphate and elevated the concentrations of blood urea nitrogen and calcium in comparison with values of PQ- treated rats, Dx did not affect the concentrations of uric acid, sodium and potassium. In conclusion, the treatment of PQ- induced toxicity with Dx in rats has limited value in correction of most kidney function tests.

Key words: Dexamethasone, paraquat, electrolytes, rats

تأثير الايكساميثازون في علاج اضطراب وظائف الكلى الناتج عن معاملة ذكور الجرذان البالغة بالباراكوات

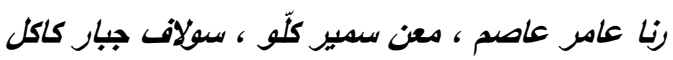

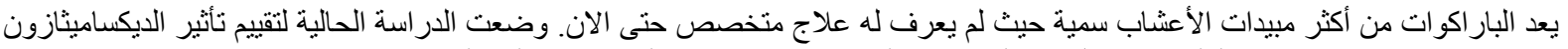

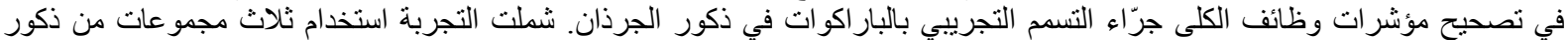

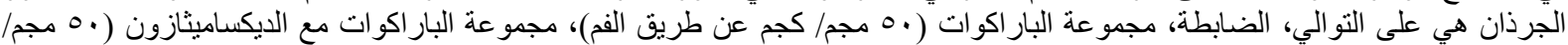

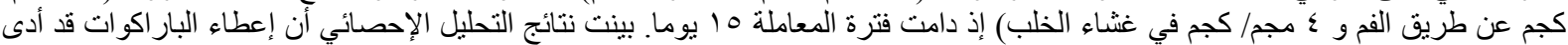

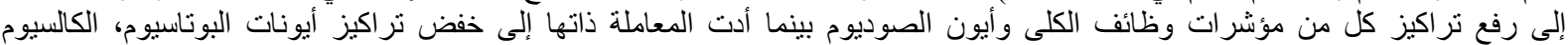

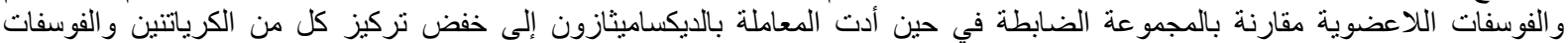

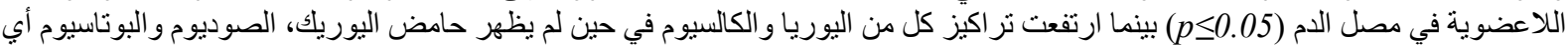

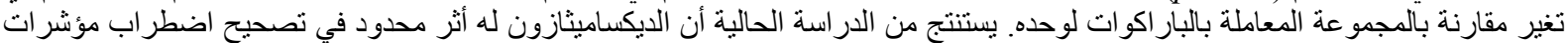
وظائف الكلى جرّاء التسمم بالبار اكوات.

\section{INTRODUCTION}

\section{المقدمــة}

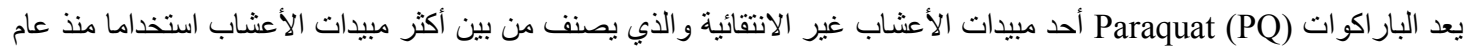

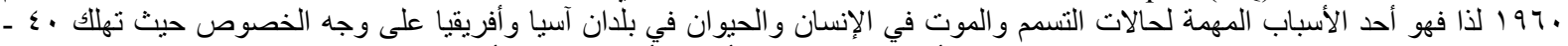

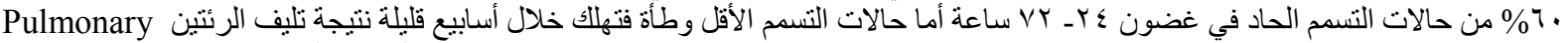

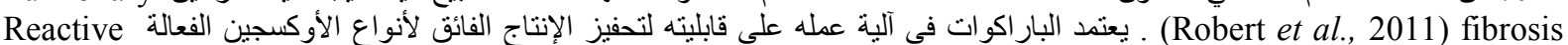

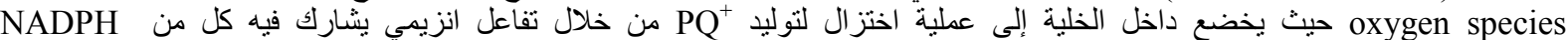
NADH ، NADPH cytochrome C reductase ، cytochrome P-450 reductase

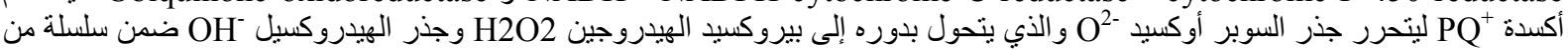

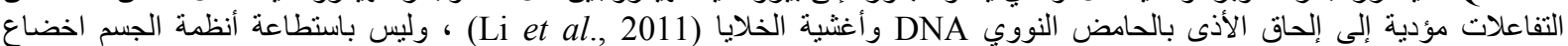

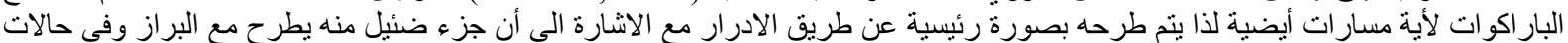

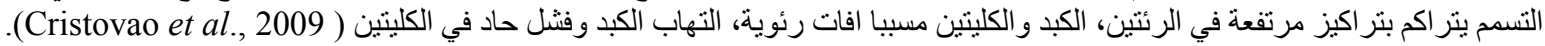

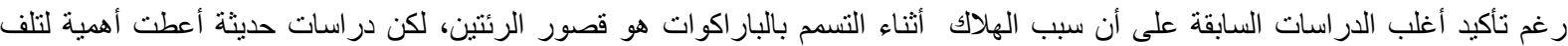

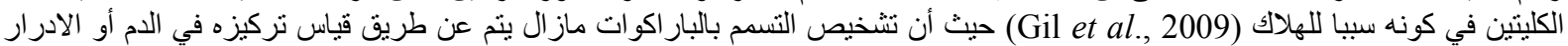

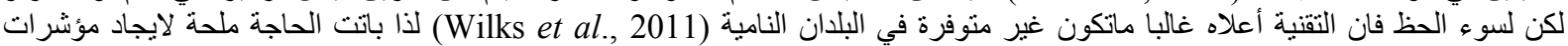


لتشخيص التسم والتتبؤ عن مصير الحالة بصرف النظر عن فترة التعرض لذا يمكن لمؤشرات وظائف الكليتين باعتبار ها احدى الأعضاء المنضررة أن تشير الى حالات التسمم بالبار اكوات (Gil et al., 2009).

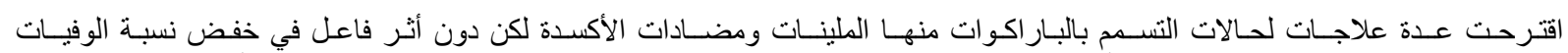

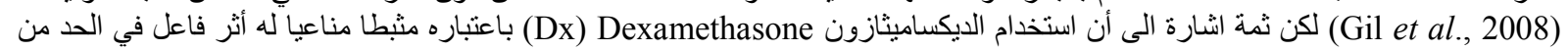

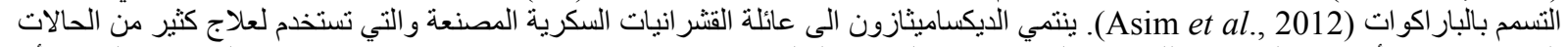

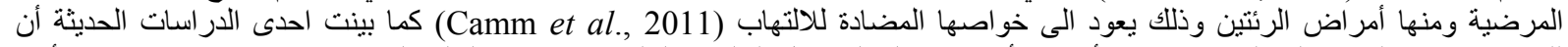

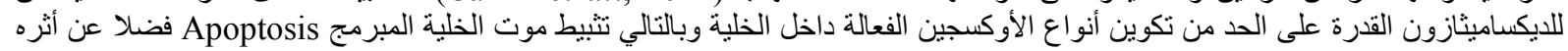

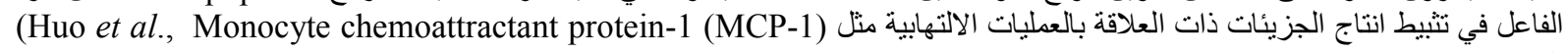

تهدف الدراسة الحالية الى التعرف على التأثير العلاجي للايكساميثازون تحديدا في اضطر اب مؤشرات وظيفة الكليتين جرّاء التسمم التجريبي بالبار اكو ات في ذكور الجرذان.

\section{MATERIALS and METHODS المواد وطرق العمل}

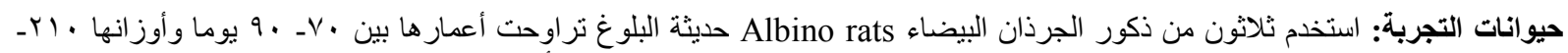

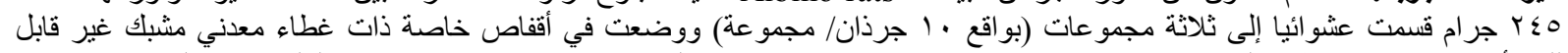

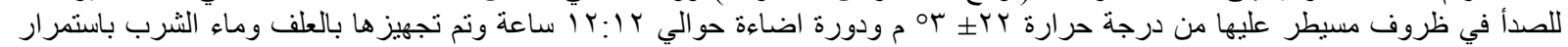

وبصورة حرة Ad libitum

غذيت حيو انات التجربة على خلطة علفية تم الحصول على مكوناتها الأساس من الأسواق المحلية وقد حضرت مع الاخذ بنظر الاعتبار المتطلبات

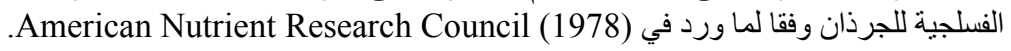

$$
\text { تصميم التجربة: استخدمت في الدر اسة الحالية ثلاثة مجمو عات وكما يلي: }
$$

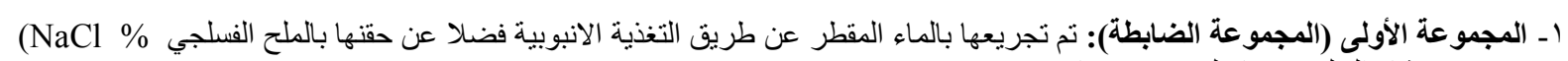

$$
\text { Y }
$$

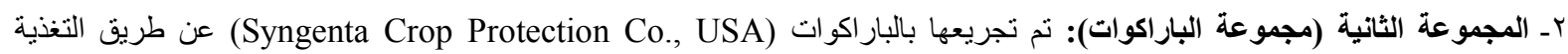

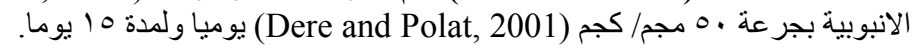

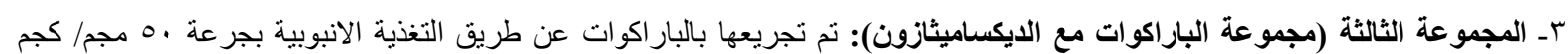

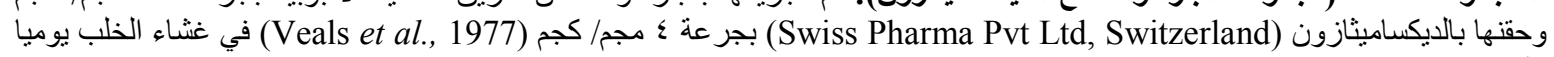

ولمدة و 10 يوماها بالايكام.

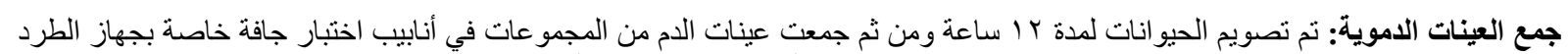

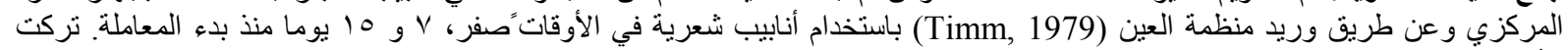

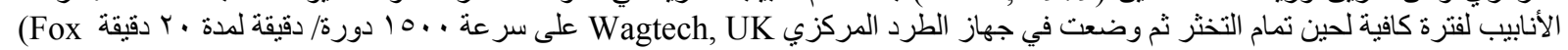
( et al., 1997)

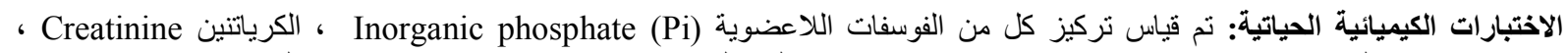

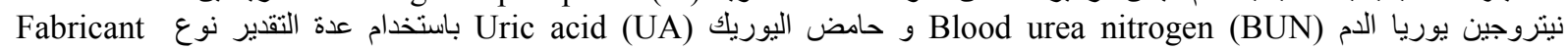
Biotech 2601 UV/VIS double وإذ نم قياس الامتصاص الضوئي للعينات باستخدام جهاز المطياف الضورئي BioLabo SA. France

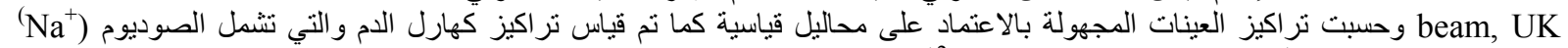

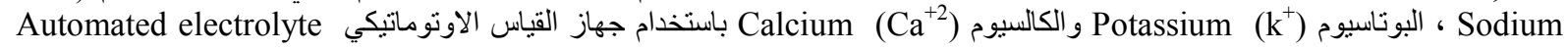
analyzer SmartLyte. Diamond. USA.

التحليل الاحصائي: نم إخضاع البيانات الى اختبار تحليل التباين (Steel and Torrie, 1980) حيث وجدت الفروقات بين متوسطات المجمو عات

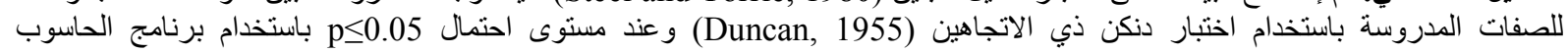
.Statistical package for social sciences (SPSS)

\section{RESULTS}

النتائج

أن النتائج التي تم الحصول عليها من الدراسة الحالية تؤكد دور البار اكوات السلبي في احداث أذى الكليتين فضلا عن دور الديكساميثازون في الحد من ذللك الأذى (جدول الني ن) 
جدول 1: نأثثير البار اكوات مع أو بدون الديكساميثازون في مؤشرات وظيفة الكلى.

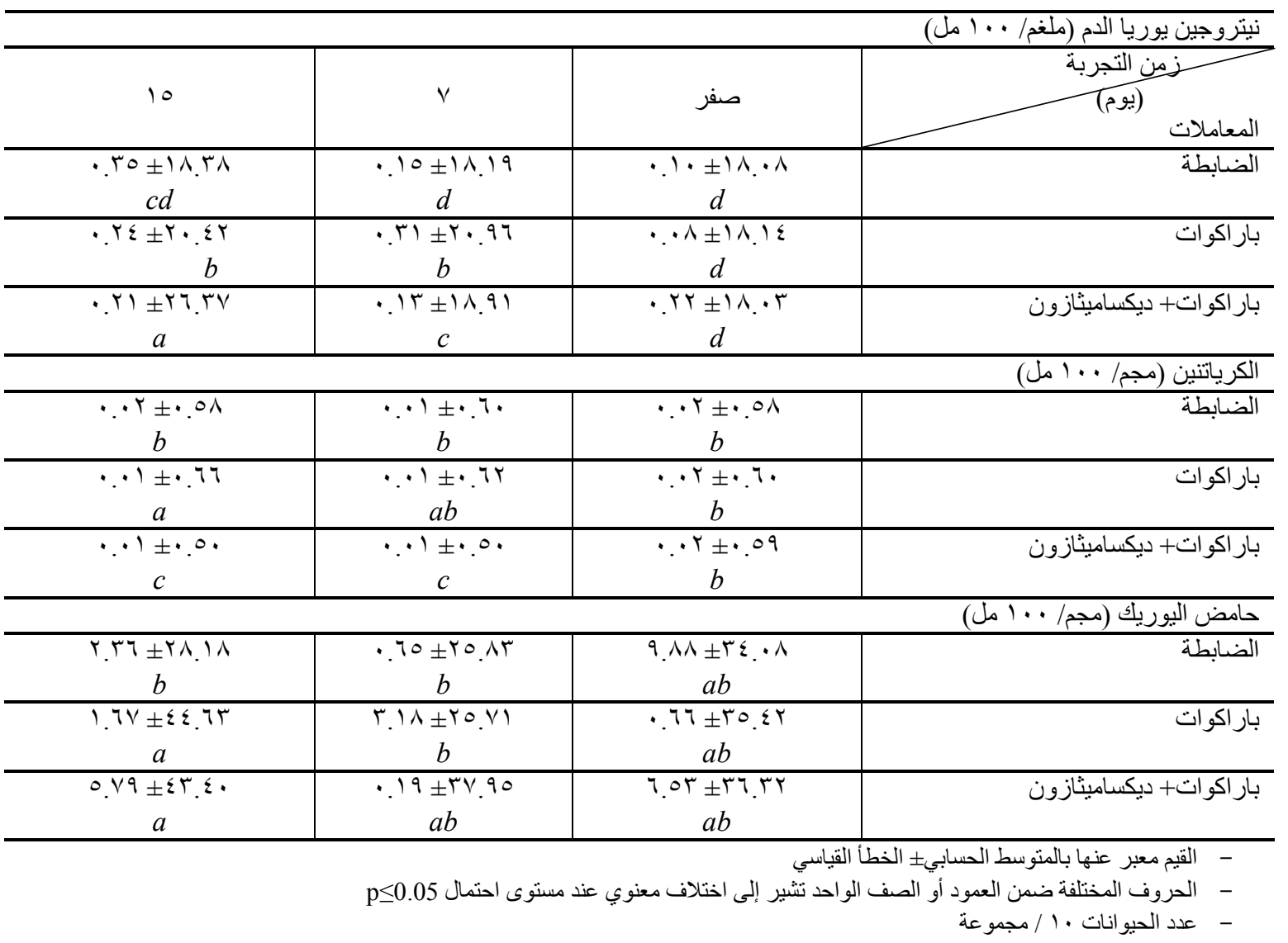

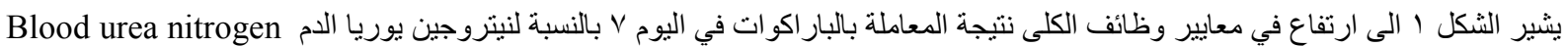

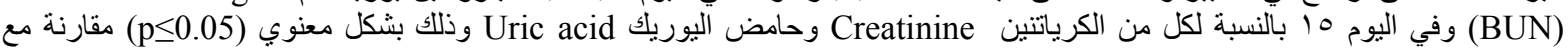

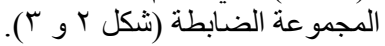

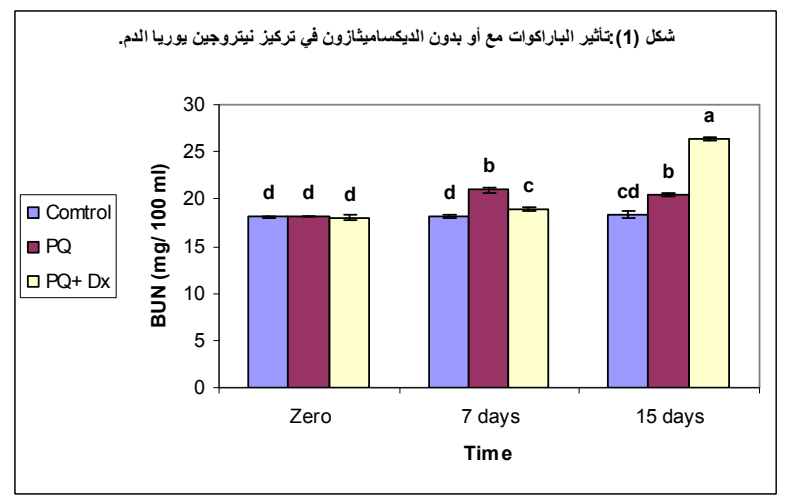

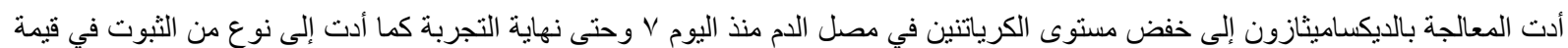

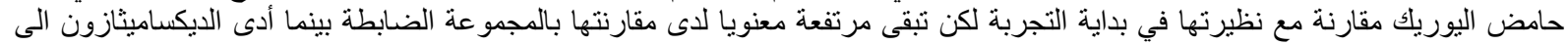

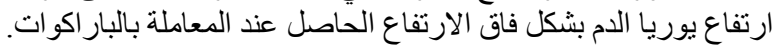
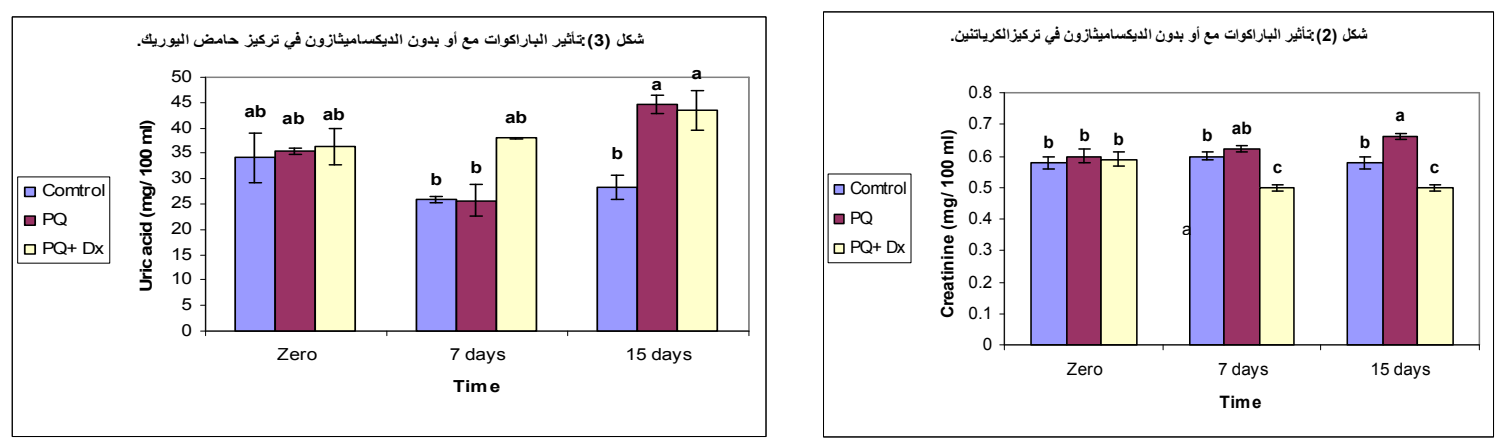
$\underline{\text { Assiut Vet. Med. J. Vol. } 58 \text { No. } 134 \text { July } 2012}$

ومن معاينة الجدول ا، يتضح أن المعاملة بالديكساميثازون كان لها بعض التأثيرات المعدلة لتر اكيز كهارل دم الجرذان المعاملة بالباركوات. جدول Y : تأثثر البار اكوات مع أو بدون الديكساميثازون في مستوى الكهارل وبعض المعادن في مصل الدم.

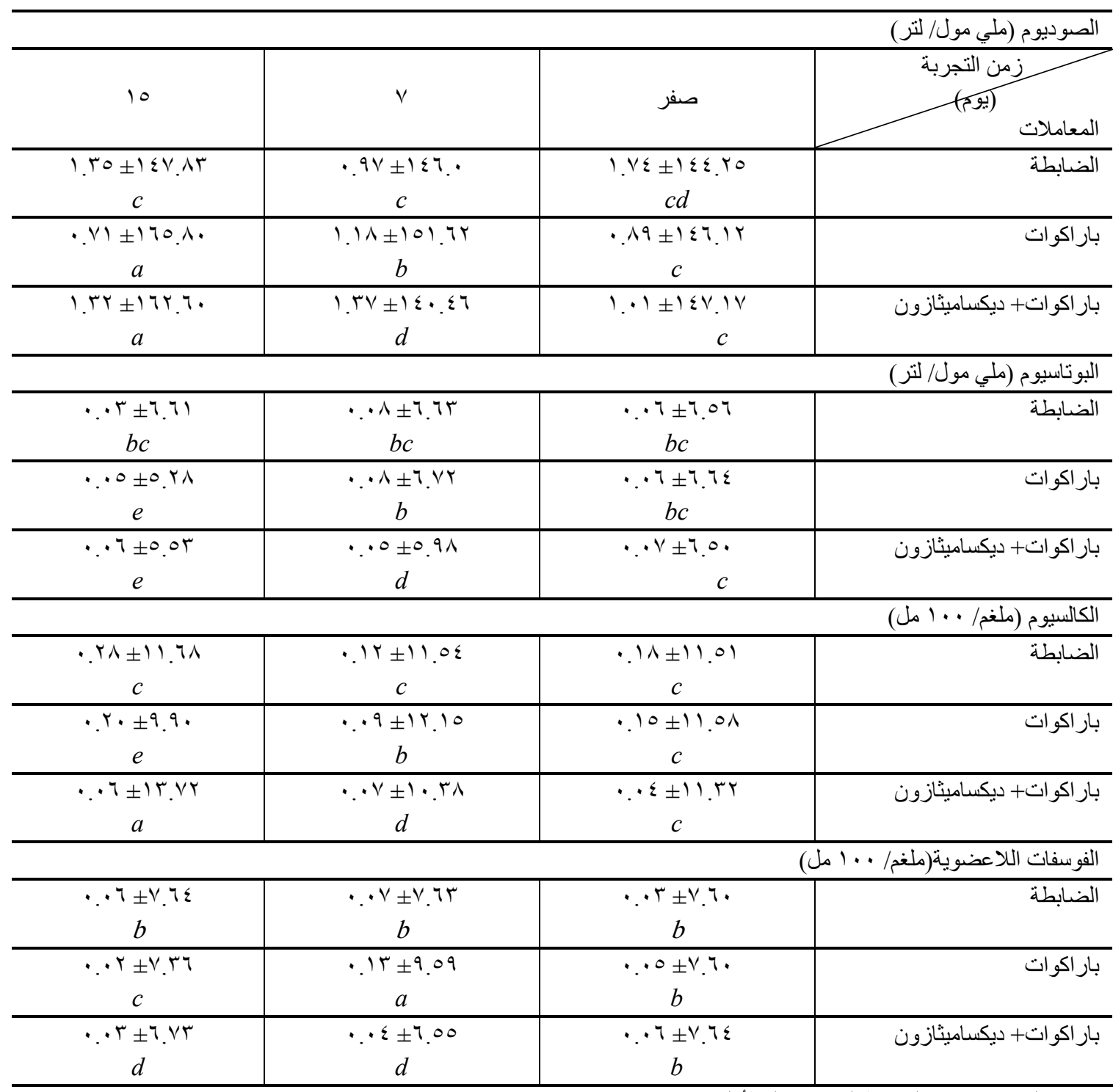

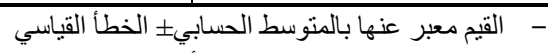

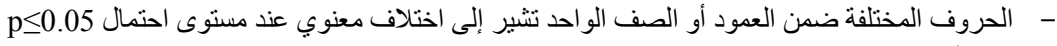

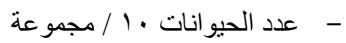

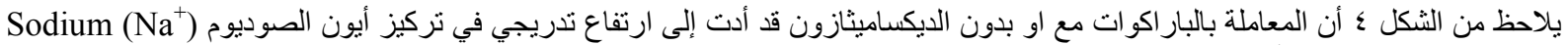

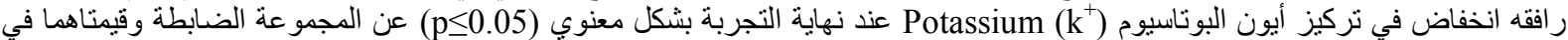

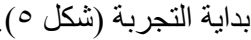
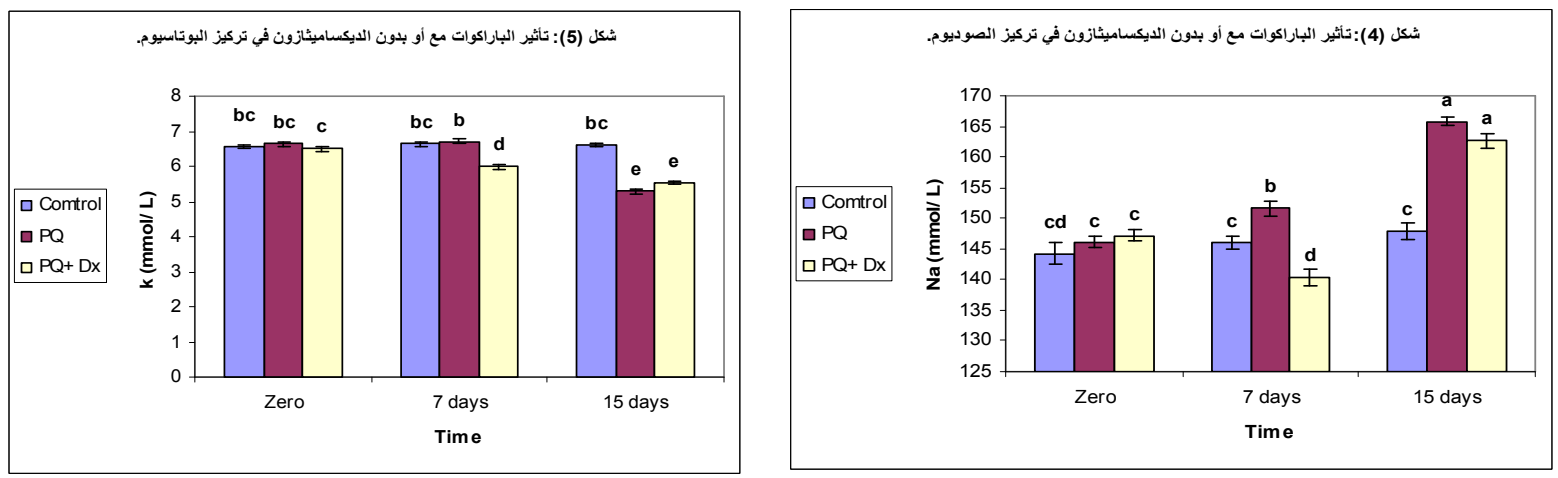


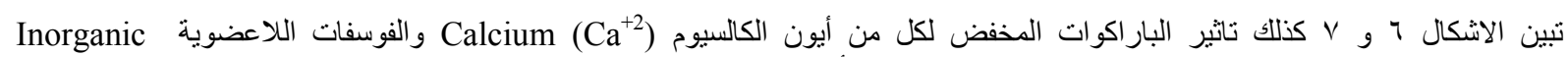
phosphate (Pi)
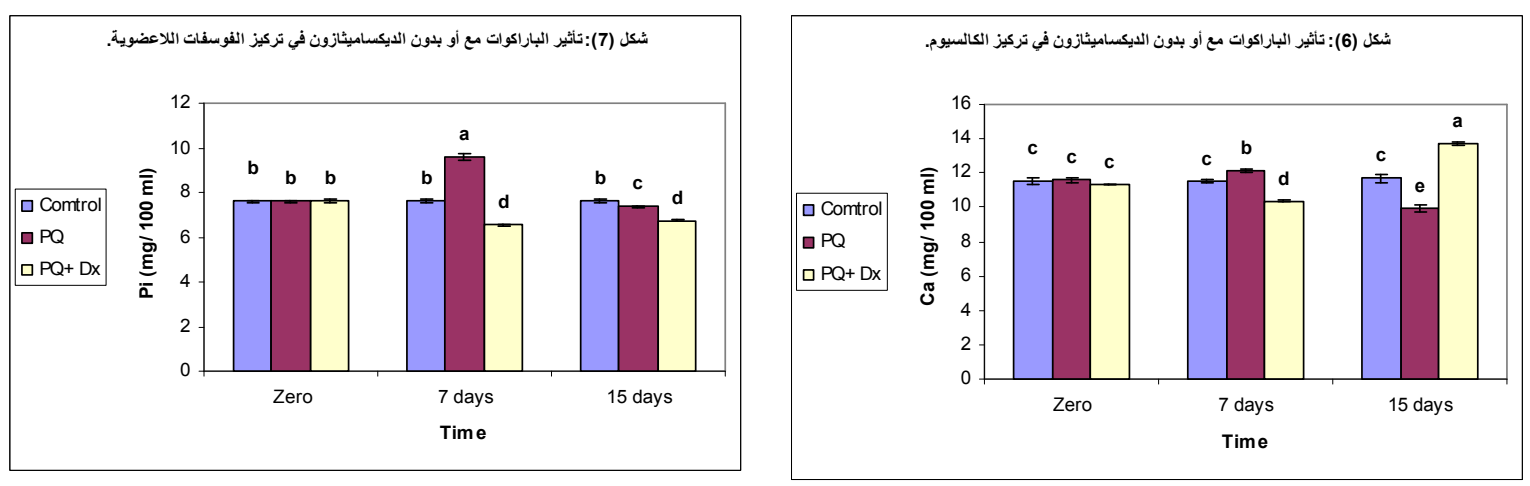

DISCUSSION

المناقشة

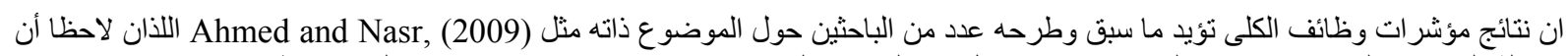

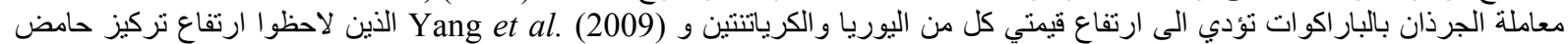

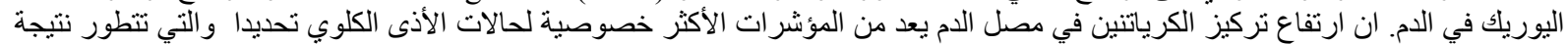

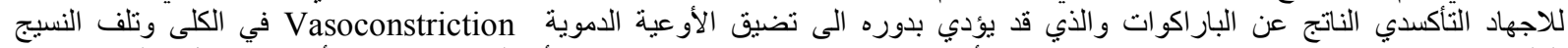

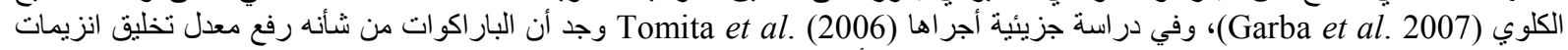

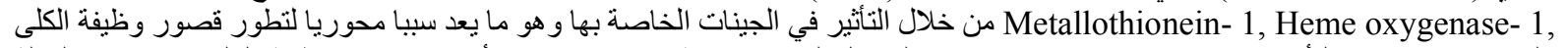

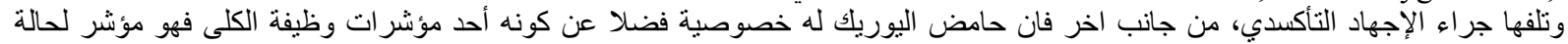

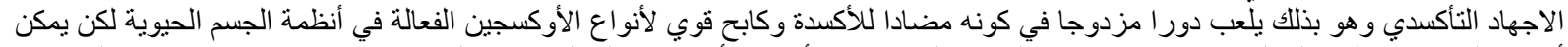

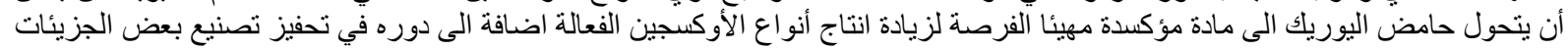

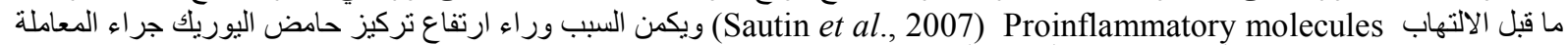

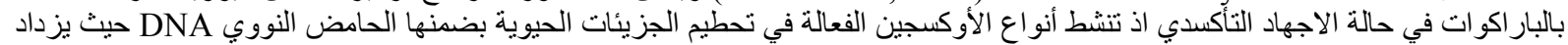

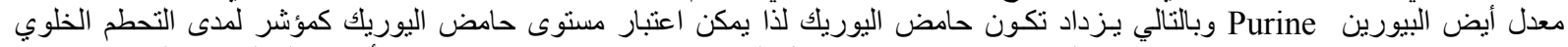

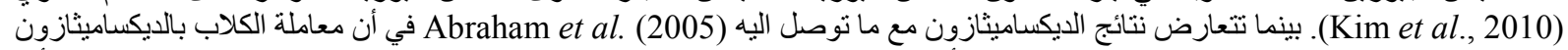

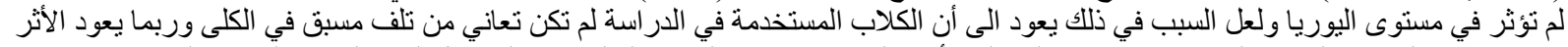

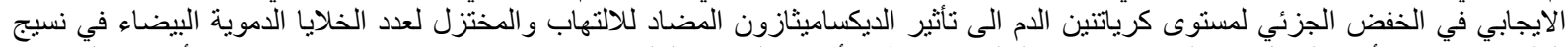

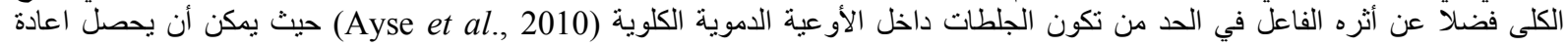

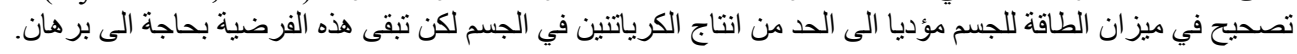

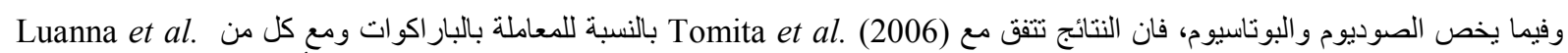
(1997), Bhutada et al. (1991), Sandle and Mc Glone, (1987)

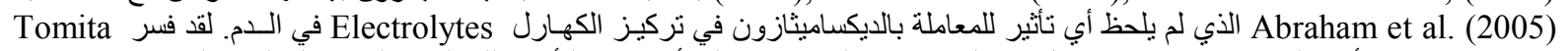

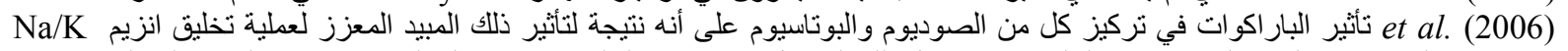

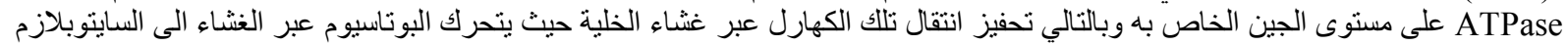

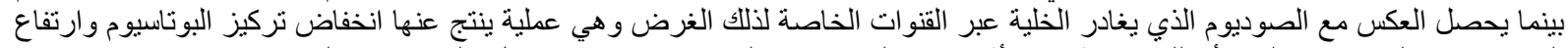

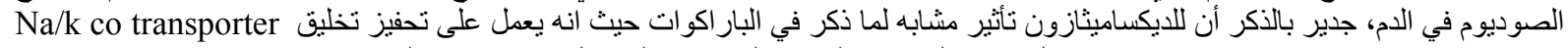
(Luanna et al., 1997) protein

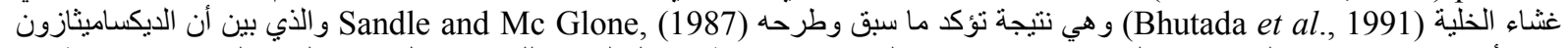

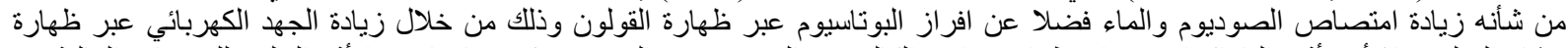

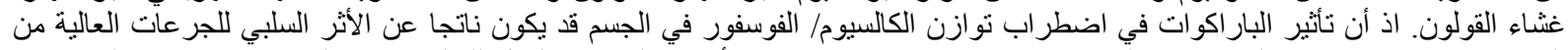

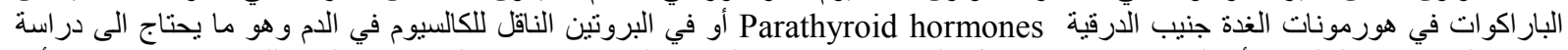

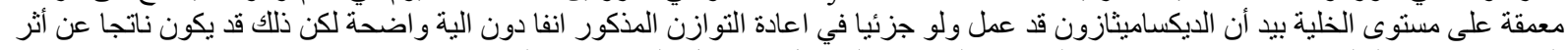

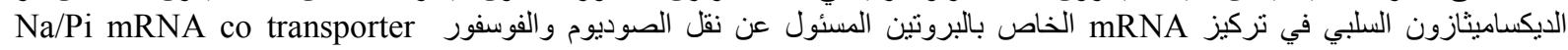
(Levi et al., 1995) protein

\section{REFERENCES}

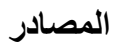

Abraham, G.; Gottschalk, J. and Rupert, F. (2005): Evidence for ototopical glucocorticoid- induced decrease in hypothalamic- pituitary- adrenal axis response and liver function. Endocrinology, 146, 7: 3163-3171.

Ahmed, M.A. and Nasr, H.M. (2009): Evaluation of ptective effect of omega 3- fatty acids and selenium on paraquat intoxication in rats. Slovak J. Anim. Sci., 42, 4: 180-187.

American Nutrient Research Council. (1978): "National Requirements of Laboratory Animals". Washington DC., National Academy of Sciences, pp. 7-27. 
Asim, R.A.; Kalo, M.S. and Kakel, S.J. (2012): Role of dexamethasone in correction of liver functions following oral administration of paraquat in male rats. Journal of Sciences and Technology, (under press).

Ayse, Er.; Feray, A.G.C.; Altan, K.U.; Bunyamin, T.; Muammer, E. and Enver, Y. (2010): Effects of enrofloxacin, flunixin and dexamethasone on indicators of oxidative and organ damage in lipopolysaccharide-induced endotoxemia. Journal of Animal and Veterinary Advances, 9, 10: 1495-1500.

Bhutada, A.; Wassynger, W.W. and Beigis, F. (1991): Dexamethasone markedly induces Na,K-ATPase mRNA in a rat liver cell line. The Journal of Biological Chemistry, 266, 17: 10859-10866.

Camm, E.J.; Tijsseling, D.; Richter, H.G.; Adler, A.; Hansell, J.A.; Derks, J.B.; Cross, C.M. and Giussani, D.A. (2011): Oxidative stress in the developing brain: effects of postnatal glucocorticoid therapy and antioxidants in the rat PLoS one. BMC Neurosci., 6, 6: 211- 224.

Cristovao, A.C.; Choi, D.H.; Baltazar, G.; Beal, M.F. and Kim, Y.S. (2009): The role of NADPH oxidase 1derived reactive oxygen species in paraquat-mediated dopaminergic cell death. Antioxid. Redox Signaling, 11 9: 2105-2118.

Dere, E. and Polat, F. (2001): The effect of paraquat on the activity of some enzymes in different tissues of mice (Mus musculus - Swiss albino). Turk. J. Biol., 25: 323-332.

Duncan, D.B. (1955): Multiple range and multiple "F" test. Biometric., 11: 1-42.

Fox, J.G.; Cohen, B.J. and Loew, F.M. (1997): "Laboratory Animal Medicine". Academic Press., London, pp. 119-120.

Garba, S.H.; Adelaiye, A.B. and Mshella, L.Y. (2007): Histopathological and biochemical changes in the rats kidney following exposure to a pyrethroid based mosquito coil. J. Applied Sci. Res., 3, 12: 1788-1793.

Gil, H.W.; Kang, M.S.; Yang, J.O.; Lee, E.Y. and Hong, S.Y. (2008): Association between plasma paraquat level and outcome of paraquat poisoning in 375 paraquat poisoning patients. Clin. Toxicol, 46: 515-518.

Gil, H.W.; Yang, J.O.; Lee, E.Y. and Hong, S.Y. (2009): Clinical implication of urinary neutrophil gelatinaseassociated lipocalin and kidney injury molecule-1 in patients with acute paraquat intoxication. Clin. Toxicol., 47: 870-875.

Huo, Y.; Rangarajan, P.; Ling, E-A. and Dheen, T. (2011): Dexamethasone inhibits the Nox-dependent ROS production via suppression of MKP-1-dependent MAPK pathways in activated microglia. BMC Neurosci., 12: 49-56.

Kim, J.H.; Gil, HW.; Yang, J.O.; Lee, E.Y. and Hong, S.Y. (2010): Serum uric acid level as a marker for mortality and acute kidney injury in patients with acute paraquat intoxication. Nephrol. Dial. Transplant., 10: $1-7$.

Levi, M.; Shayman, J.A.; Abe, A.; Gross, S.K.; McCluer, R.H.; Biber, J.; Murer, H.; Lotscher, M. and Cronin, R.E. (1995): Dexamethasone modulates rat renal brush border membrane phosphate transporter mRNA and protein abundance and glycosphingolipid composition. The Journal of Clinical Investigation, 96: 207-216.

Li, Q.; Peng, X.; Yang, H.; Wang, H. and Shu, Y. (2011): Deficiency of multidrug and toxin extrusion 1 enhances renal accumulation of paraquat and deteriorates kidney injury in mice. Mol. Pharm. 8, 6: 2476-2483.

Luanna, K.; Putney, J.D.; Brandt, J. and O'Donnell, M.E. (1997): Effects of dexamethasone on sodiumpotassium- chloride Cotransport in trabecular meshwork cells. Investigative Ophthalmology \& Visual Science, 38, 6: 1120-1128.

Roberts, D.M.; Wilks, M.F.; Roberts, M.S.; Swaminathan, R.; Mohamed, F.; Dawson, A. and Buckley, N.A. (2011): Changes in the concentrations of creatinine, cystatin $\mathrm{C}$ and NGAL in patients with acute paraquat self-poisoning. Toxicol. Lett., 202, 1: 69-74.

Sandle, G.I. and McGlone, F. (1987): Acute effects of dexamethasone on cation transport in colonic epithelium. Gut., 28: 701-706.

Sautin, YY.; Nakawawa, T. and Zharikov, S. (2007): Adverse effects of the classic antioxidant uric acid in adipocytes: NADPH- oxidase mediated oxidative/nitrosative stress. Am. J. Physiol. Cell Physiol., 293: 584-596.

Steel, R.G.D. and Torrie, J.H. (1980): "Principles and Procedures of Statistic". 2nd ed., Mc- Graw Hill Book Company., New York.

Timm, K. (1979): Orbital venous anatomy of the rat. Lab. Animals Sci., 2: 663-670.

Tomita, M.; Okuyama, T.; Katsuyama, H. and Ishikawa, T. (2006): Paraquat-induced gene expression in rat kidney. Organ Toxicity and Mechanisms, 226: 134-132.

Veals, J.W.; Korduba, C.A. and Symchowicz, S. (1977): Effect of dexamethasone on monoamine oxidase inhibition by iproniazid in rat brain. European Journal of Pharmacology, 41, 3: 291-299.

Wilks, M.F.; Tomenson, J.A.; Fernando, R.; Ariyananda, P.L.; Berry, D.J.; Buckley, N.A.; Gawarammana, I.; Jayamanne, S.; Gunnell, D. and Dawson, A. (2011): Formulation changes and time trends in outcome following paraquat ingestion in Sri Lanka. Clinical Toxicology, 49: 21-28.

Yang, J.O.; Gil, H.W.; Kang, M.S.; Lee, E.Y. and Hong, S.Y. (2009): Serum total antioxidant statuses of survivors and nonsurvivors after acute paraquat poisoning. Clin. Toxicol., 47, 3: 226-229. 